\title{
FINANCIAL PLANNING METHODS OF HUNGARIAN MUNICIPALLY OWNED COMPANIES
}

\author{
Menich-Jónás Judit - Kovács-Rump Henetta
}

\begin{abstract}
Local governments set up companies to carry out certain of their public tasks defined by law. To do this, they have to provide their companies with property that they must manage responsibly. Therefore, the management and financial stability of both the local government and the municipal company affect the operation of the other organization. The current legislation does not clearly define when a company is considered as municipally owned. Although planning is an essential part of efficient and stable operation, in Hungary, planning is not required by law for these companies. But they usually prepare an annual business plan, which is approved by the owner.

In our research, we examined whether companies can use the budget planning methods of the owner municipality. Generally speaking, these companies do not plan in a uniform structure, as there are no regulations for the formal and content elements of their business plan. The financial plans are not standardised and do not provide a financial presentation of the implementation of the previous year's plan, thus comparisons cannot be made. The main difficulties in planning are the lack of managerial accounting and sufficient and adequate human resources. The Covid-19 pandemic has also made planning for these companies more difficult, as in 2020 it was not yet possible to foresee how much the pandemic would affect the operations and financing of each company.
\end{abstract}

Keywords: business planning, regulation, development

JEL: $H 70$

\section{Introduction}

In Hungary, municipally owned companies also perform public functions and manage national assets. Hungary's Constitution stipulates that the property of local governments is national property, which is managed by both state and municipally owned companies. That is why it is extremely important that these enterprises operate profitably, manage public funds efficiently and effectively, and apply the principle of continuing the business at all times (Hegedűs - Zéman, 2016). There is no legal obligation to make planning mandatory for them, however, a good plan facilitates the operation of the company, and managers may even be held accountable under the plan. At the beginning of this paper, we want to explain what exactly we mean by a municipally owned company in Hungary, and why the presence of these organisations is so important. We will then discuss the development of corporate planning, followed by presenting the methods used by companies to prepare their plans and the methods used by municipally owned companies.

\section{Materials and Methods}

Our study focuses on municipally owned companies. The research methods used in the present study were exploratory method and document analysis within that. To implement the method in practice, we collected data and reviewed several national and international studies. 
The aim of the research is to explore how the corporate planning methodology has evolved in Hungary and what planning options are available to municipally owned companies. In terms of their financial planning prepared in the framework of business planning, which methods are used in practice today. We analyzed the business planning of 34 Hungarian municipal companies, on the basis of which we identify the difficulties of financial planning.

\section{Theoretical Background}

The definition of municipally owned companies is not clearly set out in Hungarian legislation. Act CXXII of 2009 on the More Economical Operation of Publicly Owned Companies defines a publicly owned company, according to which a publicly owned company is a company in which the Hungarian State, a local government, an association of local government with a legal personality, a national minority government, an association of national minority government with a legal personality, a budgetary body or a public foundation has a majority influence, either individually or jointly. However, the question may arise as to whether or not a company which does not have majority control but is owned by the municipality is also a municipally owned company. The legal regulation of municipal enterprises is based on the Civil Code, but from an ownership point of view, it does not distinguish between state-owned and municipal-owned companies (Hegedûs - Molnár, 2019).

The share that the state and the local government is entitled to, ie their companies, belongs to the national property. The Constitution of Hungary designates the service of the public interest and the satisfaction of common needs as the aim of the management and protection of national property. In Hungary, the Constitution formulates principles according to which organizations owned by local governments operate independently and responsibly in accordance with the requirements of legality, expediency and efficiency in the manner specified by law. (Lehoczki, 2018) Every organization managing public funds is obliged to be accountable to the public for its management from this source. Local governments set up companies to carry out certain of their public tasks defined by law. To do this, they have to provide their companies with property that they must manage responsibly. Therefore, the management and financial stability of both the local government and the municipal company affect the operation of the other organization. And planning is an essential part of efficient and stable operation.

Planning as a system spread in the socialist society of the twentieth century. Today, corporate planning is present in many industries in Hungary, so it is also a term used in the case of municipally owned companies. László Szőllősi and István Szűcs define planning as follows: Planning, in general, is the outlining of a desirable future state and the definition of the path(s) and conditions (means) that will enable its achievement. (Szőllősi - Szűcs, 2015).

Until the beginning of the twentieth century, corporate planning appeared informally in the minds of managers, there was no need to record their ideas in detail in writing. After the Second World War, from the 1950s onwards, the growing size of companies, the expansion of the scope of activities, the intensification of market competition and the modification of other environmental factors have gradually forced the "institutionalization" of foresight, the documentation of appropriations in writing. It is called formal planning by researchers of the developmental history of strategic thinking. (Mohai, 1989).

The first manifestation of formalized planning in American and Western European companies was the simple financial planning. The essence of this planning system was the short-term 
approach, as well as the prescription and accountability of financial indicators. (Gardner et al. 1986) In conscious business foresight, formalized long-term planning has taken over the role from annual financial planning. Long-term planning was also financially based, but it has looked much further ahead, usually for 5-7 years, but there have also been planning targets for 10-15 years (Payne, 1963). Nowadays Hungarian municipally owned companies usually compile their business plans annually, longer-term planning is not yet typical in this sector. For these companies, the law does not prescribe the formal and substantive elements of the plan approved by the owner, a financial planning model has not yet been developed for Hungarian companies performing public tasks, which would be used in connection with their business planning.

Business companies typically prepare the profit and loss account and balance sheet plan as part of the business plan, but the latter is not applied by Hungarian municipally owned companies. In our opinion, in addition to profitability, it would be very important to present the financial situation, as it shows the process of the company's solvency and the development of its assets.

The business plan is able to show whether it is worthwhile to start the implementation of the given enterprise or development idea, or whether, according to the objective analysis, our enterprise can become successful (Lakrovits - Nagy, 2012). In Hungary, companies do not have the obligation to prepare a business plan at the legal level; the Accounting Act only makes business reporting mandatory for some companies, but it does not cover planning. Even if companies were obliged to prepare a business plan and present the profit plan and financial plan in it separately, there is no integrated directive and methodology for compiling them, thus different plans with different structures could be created.

Planning is also very important for management, leaders, investors and owners. A company sets out in its plans the goals it wants to achieve in the future. We can distinguish between financial plan, marketing plan, human resource plan, production and service plan. (Illés - Vajna, 2013) Depending on the stakeholders to whom the company wants to present its plan, some plans will become more prominent. If a business plan is prepared for the internal stakeholders of the company, the plan is used for making internal decisions and it is necessary to develop a very precise management-financial-operational framework in terms of the content of the plan. In the case of municipally owned companies, the business plan is usually prepared annually for the internal stakeholders, therefore the accurate and well-founded preparation of the profit plan and financial plan is essential. The validity of planning can be measured by efficiency, which shows how the factual data differ from those in the plan. For efficiency effectiveness is a necessary condition. The nature of goals and objectives - which determine effectiveness - may differ greatly for different companies. Nevertheless, there is a set of generally accepted principles and actions that can enhance effectiveness. Municipally owned companies are spending taxpayers' and citizens' money who are entitled to information therefore accountability, transparent plnning and financial reporting are essential in their case. Comparability is therefore very important in the implementation of planning, which can be achieved by analyzing previous data. (Mansur - Tangl, 2018) In each case, it is important to examine whether the plan presented to the owner is appropriate and reasonable.

\section{Determining the time horizon of planning}

The planning system is divided into three separate time periods, the aim of which is to ensure the short-, medium- and long-term solvency of the company with the proper management of financial management and to maintain a balanced balance sheet structure and financing in the following years. The literature on planning deals a lot with the time horizon of planning in the field of 
corporate planning. The short term is set in 1-2 years, the medium term in 3-5 years, and the longer term in 5 years. The short and medium term are handled on unified opinions in the literature, however, there are differences in the definition of the longer term (Lukács, 2005). According to László Horváth, "Long-term is generally considered to be the time interval after which the people, tangible assets (fixed assets), products and technologies operating in the company quit, become obsolete, and lapse" (Horváth, 1973). It is also important to understand that plans for different time periods are not independent of each other, but are integrally linked. The concretisation of plans covering a longer period is realized in the plans prepared for shorter periods, therefore the substantiation of the long-term plan is extremely important.

By determining the different time periods, the time that is needed for the company to implement the strategy should be taken into account. If it exceeds one year, it is justified to use business planning for a period longer than one year. The time horizon of a company's business plan can be defined in 2-3 years. A period of three years is the most often recommended in the literature as well (Kresalek, 2007). In Hungary, on the other hand, it is typical for municipally owned companies to prepare their business plan annually in which the financial plan applies to a given year, multiannual financial planning and long-term written strategies are rarely implemented. In the course of our research, we have come to the conclusion that the managers and economic leaders of municipally owned companies prepare their own multi-year plan for themselves in order to see the return and costs of a larger investment.

\section{Planning methods}

As we mentioned earlier, corporate planning was initially informal. This method was characterized by the fact that the managers of the company did not prepare planning documentation, as planning was a way of thinking, the plan and the goal to be achieved were formulated in the mind of the manager. This type of planning has been replaced by formal planning, as with technical development and rapid market change, informal planning was no longer applicable. It is important to emphasize that informal planning is still present in smaller companies, but in large companies, where there are several departments or processes, it is necessary to prepare the planning documentation in writing, to which companies stick during their operation. We can talk about formal planning if the company's processes are regulated to establish the plan, and the results are recorded in writing. This method spread in developed countries after World War II and became the dominant planning trend in the $60 \mathrm{~s}$, it was financial planning at that time. The complexity of corporate processes reached a critical level then, that already required methodological help to establish corporate management. The market was much more predictable at this time. Technological changes, the increasingly rapid change of the environment, the decrease of market predictability required the application of new methods. Thus, long-term planning became widespread, focusing not only on short-term profit generation, but also on achieving longer-term corporate goals. By the 1970s, formal planning had been expanded so that companies took their own capabilities into account and incorporated ever-changing strategies into planning. (Lukács, 2005)

Strategic planning includes changes that affect the entire system of the company. It is usually long term. According to Chikán (2003), the task of the strategy is to “... organize the stakeholders of the company in a way that makes forms of movements desirable and possible for the stakeholders that effectively serve the fundamental goals of the company". Strategy is the guiding thread of the company, the comprehensive goals of the company's development is planned for a 
long-term period which includes large-scale changes. The main task of strategic planning is to identify and respond to the organization's opportunities in a timely manner.

The primary step in planning is to define goals, which are broken down into specific tasks, and the necessary resources and conditions are assigned to them. Planning can basically be implemented along three principles:

- top-down, when the goals of the organization are broken down into unit-level sub-goals, and tasks and budgets are assigned to it;

- bottom-up, when planning is prepared from the lower units of the organization;

- while in countercurrent planning, the plan is formed by a combination of the previous two.

In this case, each organizational unit has a certain degree of autonomy, but the purpose of the organization is predefined (Felföldi et al. 2013).

\section{Differences compared to municipalities}

In Hungary, the operation and management of local governments are more strictly regulated than those of companies, so the laws and related government decrees also contain basic framework rules for planning activities. Legislation on planning focuses primarily on budget planning, medium- and long-term planning tasks are only mentioned at the level of the regulations. The basis of the local government's management is the annual budget, which is regulated in the municipal decree. The budget is the annual financial plan of the local government, which should be based on the economic program that can be considered as a long-term plan and is typically for a municipal cycle. There is no prescribed system of requirements for the structure and content of the economic program, the local governments determine themselves their long-term objectives and the tools used for their implementation. It is necessary to incorporate the goals and tasks defined in the economic program in the annual budget. With regard to medium-term planning, we can also find a short legal provision according to which the local government annually determines the expected amount - arising from its transactions for the three years following the financial year - of its own revenues as defined in the legislation issued on the basis of the Stability Act (Act CXCIV of 2011 on the economic stability of Hungary) and the payment obligation arising from its debt-generating transactions according to the Stability Act. (Sisa - Veress, 2014)

The local government's budget is separated from the state budget on the one hand, and is connected to it on the other hand, through state and other subsidies and the transferred central taxes. Both mandatory tasks delegated to local government by legislation and voluntary tasks have to financed from the budget. There are strict rules on the content of the municipal regulation on budgeting, such as no operational deficit can be planned in it. During the planning of the budget, in accordance with the provisions of the Local Government Act the appropriations and revenues necessary for the performance of the obligatory and voluntary tasks are taken into account, ie the public tasks performed and their sources. (Lentner, 2019)

The planning of local governments in Hungary has traditionally been intertwined with the concept of budgeting, but at the same time, thanks to the new accounting regulations that came into force in 2014, the management approach is beginning to spread. The new accounting system, similar to that of companies, which is basically accrual-based, already makes it possible to prepare complex plans based on financial accounting data, in the course of which various management methods can be applied. Thus, the available data and information will become comparable with the data of other market participants, and the analysis and planning procedures applied in the corporate sector will also be possible to carry out on the basis of accrual-based accounting records. 
However, all this is only possible on a theoretical level, as based on practical experience, the majority of the most common strategic analysis and planning methods in the business sector are not known at all or already have been heard by municipal decision-makers but have never been used in practice. Real strategic planning not only means the preparation of strategic planning documents, but also the continuous monitoring of planning, reporting, feedback and review of strategic plans are an integral part of the planning process, which are not yet typical of this sector. The lack of management activity is also shown by the fact that indicators are not used to monitor the fulfillment of strategic goals, strategy-making, which is exhausted in the preparation of the economic program, is mostly carried out only for compliance with legal requirements. The emphasis on short-term planning is also limited to the mandatory budget and liquidity planning.

In the municipal subsystem, the oldest and most common budget planning methods are the base-based and line-item budget planning. The essence of the line-item budgeting method is its simplicity, the pre-determined amounts for each item determine the expenditure that can be spent, however, due to the narrow room for maneuver, the organization has no interest in obtaining additional revenue in addition to the given amounts. Using the method, it is not expected to minimize the difference between the planned and the actual impact when achieving the goals, so it cannot be considered efficient, economical, or even effective. The only advantage is easy traceability. The base-based planning system is based on the performance data of the previous year which does not serve the public interest either, as it perpetuates the data and proportions of the previous years, it does not take into account the actual performance of tasks. In addition to convenience, its frequent use can be explained by its speed, cheapness and simplicity. In this method, the basis for planning the appropriations for the financial year is the original appropriation for the base year, taking into account the changes in appropriations resulting from the structural changes in the base year. However, the magnitude of the changes can only be estimated. The basis-based planning practice comes with that the appropriation must be adjusted several times during the year in accordance with the rules in force. This institution-oriented planning practice is characterized by the dominance of the annual budget planning activity, so the operation and the performance of public tasks are determined by the past instead of the future, and program planning is not typical. (Sisa Veress, 2014) In most cases, information reaches the stakeholders only after the economic event has occurred, so the criterion of future-orientation cannot be met.

Based on the above, it can be concluded that it is currently not advisable for municipal-owned companies to adopt the planning practices of their owners, as for a company it is even more important to adopt a management approach. In the case of a municipally owned company, it is not enough to plan expenditures and revenues, corporate planning must also include a balance sheet plan. Organisations and companies operating in the municipal sector require different corporate governance solutions than companies operating in the market sector, as they have different missions, objectives, financing possibilities and legal conditions. However, despite these differences, it may be useful to study and adapt the management systems (controlling system, management information system, management accounting system, IT system) used in the market sector. In order to provide an accurate, fast, flexible and high-quality public service, it is essential to introduce a modern, methodologically sound planning system and a management approach. In order to bring the planning of local governments and their companies closer together, further training of financial professionals and decision-makers employed by the local governemnts would be needed. 


\section{Financial planning in practice}

Today, companies prepare financial plans as part of their business plan, but it should be remembered that financial planning has been around since the second half of the 20th century. Financial planning is characterised by the fact that companies first describe their strategic plan and then use it as a basis for drawing up the company's financial plan, providing the financial resources needed for the company's operations. An important element of financial planning is liquidity planning, which ensures the balance between cash inflows and outflows. In preparing the plan, the balance of income and expenditure, i.e. the projected profit of the enterprise, must be carefully worked out. In addition, it is important to draw up a projected balance sheet, which is not seen in the financial planning practices of municipally owned companies (Balaton et al. 2017).

Financial planning is necessary for long-term corporate operations. In practice, the importance of planning in companies is most often seen in multinational companies, and it is not typical for small and medium-sized enterprises to apply it in writing. As far as municipally owned companies are concerned, I consider it important to point out that in Hungary they are almost $80 \%$ small companies in terms of company size. The following table shows the distribution by company size, in which I have highlighted the exact number of municipal companies with less than 5 employees within the small company sector.

1. table. Classification of municipally owned companies by size of enterprise

\begin{tabular}{|l|r|r|r|r|r|}
\hline By size of enterprise & \multicolumn{1}{|c|}{2014} & \multicolumn{1}{|c|}{2015} & \multicolumn{1}{|c|}{2016} & \multicolumn{1}{|c|}{2017} & \multicolumn{1}{c|}{2018} \\
\hline $\begin{array}{l}\text { small enterprise 0-49 } \\
\text { (ppl) }\end{array}$ & 1521 & 1560 & 1517 & 1492 & 1463 \\
\hline $\begin{array}{l}\text { medium-sized enterprise } \\
\text { 50-249 (ppl) }\end{array}$ & 276 & 256 & 282 & 290 & 301 \\
\hline $\begin{array}{l}\text { small enterprise 250+ } \\
\text { (ppl) }\end{array}$ & 66 & 78 & 69 & 76 & 71 \\
\hline unknown & 31 & 32 & 36 & 26 & 17 \\
\hline 0-4 employees & 730 & 778 & 786 & 764 & 715 \\
\hline
\end{tabular}

Source: Own resource based on the tabular data set of the Central Statistical Office compiled on individual request.

While in Hungary small and medium sized companies do not typically have financial planning within their corporate planning, in the case of municipally owned companies the owner would like to see the planning whether the company is running efficiently and effectively, and if it has no liquidity problems. However, there is no legal requirement on the level of detail to be presented in the financial planning of municipal companies. The owner may have different needs that he would like to see separately broken down in the plan, but there is no single framework for companies, which makes financial planning difficult. Can smaller companies really plan on a similar basis as those that involve a particular person assisting with planning? We think it is worth thinking about this question, because in a company where the number of employees is less than 5 , they may not have enough knowledge of how to prepare a well-founded plan. It is conceivable that the accounting itself is outsourced by such companies, so it is not guaranteed that anyone at the municipally 
owned company will have financial knowledge, as the executive manager is not required to be such a professional either.

In our research, we analysed the business plans of 34 municipally-owned companies, which are classified as small and medium-sized enterprises. During the analysis, we encountered municipalities that are 100\% owners in several companies, but the business plans and financial plans of the companies are not uniform, yet the approving owner is the same. In this case, the owner may have a legitimate expectation that his companies should draw up their plans following similar principles, from which he will clearly see the financial information and objectives.

In Hungary, for municipally-owned companies, financial planning is most often prepared in the short term for one year, which is adopted annually if the owner requests it. Short-term planning is typical for these companies because municipalities adopt the ownership subsidy for the operation of the companies in their budgets on an annual basis. The managers and economic directors who are involved in the planning are therefore less able to plan for the long term, and medium- and long-term financial plans are not typically written for municipal companies. If there is no longerterm planning, the financing of longer-term investments in annual financial planning becomes unpredictable, which can affect the future operation of municipal companies. The lack of longerterm planning may also create the risk that a municipal enterprise may accumulate a significant amount of debt to ensure its liquidity. The analyzed business plans show that municipal-owned companies do not prepare an investment plan, their financial plan includes expected revenues and expected expenses and expenditures. In addition to the absence of an investment plan, in practice municipal companies are characterised by the absence of a projected balance sheet. On the basis of the financial plan, municipal companies do not report on the changes in the assets of the companies in the form of a balance sheet. In case the financial plan predicts a loss, it is important for the owner municipality to see whether the company can finance the loss from its own capital or external financing is needed. The owner would also see from the pro forma balance sheet whether or not the company plans to make major investments in the current year. As part of the business planning process, we therefore consider it is important that municipally owned companies also prepare the projection on their balance sheet alongside their financial plan and a textual strategic plan. In Hungary, the resource-oriented methods, results-oriented methods and the zerobased budgeting method are used for budget planning in local governments. The use of budget planning methods is not typical in the financial planning of municipal companies.

The budgeting method of municipally owned companies is based on the incremental budgeting method, but if the company's revenues and expenditures have been over- or under-budgeted for years, this budgeting method does not improve the soundness of the plan. In the course of the analysis, we found that municipally owned companies structure their published financial plans in line with their income statements. Activity-based costing is not common in these companies, and in the adopted business plans they plan expenses and revenues on a consolidated basis for the company as a whole. The financial plans are typically optimistic, with the gap between the plan and the actual data being larger for revenues and smaller for costs.

In the course of the analysis, we found that local governments do not always report on the development of plan-fact data in their financial plans. $14.4 \%$ of the analyzed companies presented the planned and factual data of the previous period in their plan for the given year. In our opinion, the presentation of this would be very important, because if only the planned data are included, there is no comparability point for the owner to examine how the company operates: it can stick to the amounts in the plan or the factual data are significantly different. The plan can be said to be good if its implementation is possible, the company does not deviate significantly from it in the 
course of its management. Of course, if an external effect requires a significant deviation from the plan, the owner must be informed.

Municipal companies performing public services receive significant subsidy revenues from their owners, which the municipality has to finance from its budget year by year. In 2021, due to the pandemic the budgets of local governments in Hungary were transformed. The municipalities lost a significant amount of revenue, as the revenue from the motor vehicle tax is no longer paid by the owners to the municipality, but to the state. With less revenue, municipalities may face cuts in their budget, thus being able to provide less support to the businesses they own to fulfil their public functions, which will have a significant impact on the 2021 plan of municipal companies.

\section{Conclusions}

In recent years, the importance of corporate and financial planning has become more important for municipally owned companies. The owner municipality expects to maintain a transparent, wellplanned and efficient company that generates profits year after year. In Hungary, the preparation of a written business plan and corporate planning is not common for small and medium-sized enterprises, but municipal companies of all sizes are requested by the owner to prepare an annual plan. There is no uniform framework principle for the planning of these companies, which makes it very difficult to prepare a sound financial plan. The importance of corporate planning also comes to the focus of municipal companies, as the owner municipality wants to know, in the event of a loss, how the company can finance its operations and whether it is necessary to involve external funds, which would generate debt. As municipal companies can be very different in size, political capacities, powers, functions, tasks and responsibilities, it is very difficult to find a general tool, giving general guidelines on planning methods. Given the significant differences in current planning practices, it is not appropriate for municipally owned companies to adopt the planning practices of the owner municipalities. At the same time, the introduction of a modern, methodologically sound planning system and a management approach is essential for the provision of accurate, fast, flexible and high-quality public services. Relevant legislation, which is applied and enforced is a must for a uniform planning. As a first step, it would be expedient for the local governement and the companies owned by it to jointly develop a uniform procedure to be used by the companies. It also might be possible to develop in the future some sectorial guidelines which may include concrete sectorial examples.

\section{References}

[1.] Balaton K. - Felsmann B. - Ferincz A. - Hortoványi L. - Szabó Zs. R., - Tari E. - Taródy D. (2017): Stratégiai és Üqleti tervezés. Budapest: Akadémiai Kiadó.

[2.] Chikán A. (2003): Vállalatgazdaságtan. Budapest, Aula Kiadó.

[3.] Felföldi J. - Szőllősi L. - Szűcs I. (2013): Üzleti tervezés. Debrecen: Debreceni Egyetem.

[4.] Gardner, J. R. - Rachlin, R. - Sweeney, A. (eds) (1986): Handbook of strategic planning. New York: John Wiley and Sons.

[5.] Hegedűs Sz. - Molnár P. (2019): Közǚremi vállalatok gazdálkodása. Budapest: Nemzeti Közszolgálati Egyetem. 
[6.] Hegedűs Sz. - Zéman Z. (2016): Tőkeszerkezeti elméletek érvényesülésének vizsgálata a hazai önkormányzati tulajdonú gazdasági társaságok körében. Statisztikai Sz̨mle 94(10), 1032-1049.

[7.] Horváth L. (1973): A vállalat távlati terve - Idôhorizontok, ciklusok, stratégia. Budapest: Közgazdasági és Jogi Könyvkiadó.

[8.] Illés B. - Vajna I.T.A. (2013): Vállalkozási ismeretek. Gödöllő: Szent István Egyetemi Kiadó.

[9.] Kresalek P. (2007): Tervezés a vállalkozások gyakorlatában. Budapest: Perfekt Kiadó.

[10.] Lakrovits E. - Nagy O. (2012): Üzleti terv készítése. Adó- és pénzügyi szaklap, 21(6), 1-96.

[11.] Lehoczki Z. Zs. (2018): Az állami és az önkormányzati részvétellel müködő gazdasági társaságok vagyongazdálkodására irányadó alapelvek. In: Auer Á. - Boros A. - Szólik E.(szerk.): Az Önkormányzati vagyongazdálkodás aktuális kérdései. Budapest: Dialóg Campus Kiadó, pp.101112.

[12.] Lentner Cs. (2019): Önkormányzati pénz- és vagyongazdálkodás. Budapest: Dialóg Campus Kiadó.

[13.] Lukács E. (2005): A vállalati tervek tipológiája. Ünnepi tanulmányok Czabán János professzor 70. születésnapjára. Miskolc: Miskolci Egyetem, Gazdálkodástani Intézet.

[14.] Hasan, M. - Anita, T.(2018) : Governance assessment and improvement tool for public organizations in Jordan, International Journal of research in engineering and technology 7(7), 15-23. DOI: 10.15623 /ijret.2018.0707003

[15.] Mohai Gy. (1989): A vállalati tervezéstól a stratégiai módszerekig. Budapest: Közgazdasági és Jogi Könyvkiadó.

[16.] Payne, B. (1963): Planning for company growth. New York: McGraw-Hill.

[17.] Sisa K. - Veress A. (2014): Felmérés a települési önkormányzatok tervezési módszereirôl. Statisz̨tikai Sz̧emle, 92(5), 447-473.

[18.] Szőllősi L. - Szűcs I. (2015) Az üzleti tervezés alapjai. Debrecen: Debreceni Egyetem Kiadó.

\section{Authors/Szerzők}

Menich-Jónás Judit

adjunktus

Budapesti Gazdasági Egyetem

menich-jonas.judit@,uni-bge.hu

Kovács-Rump Henetta

tanársegéd

II. Rákóczi Ferenc Kárpátaljai Magyar Főiskola

henetta.kovacs@gmail.com.

This is an open access article under the terms and conditions of the Creative Commons attribution (CC-BY-NC-ND) license 4.0.

A müre a Creative Commons 4.0 standard licenc alábbi típusa vonatkozik: $\underline{\text { CC-BY-NC-ND-4.0 }}$ 